\title{
Effect of Orchard Floor Management Practices on Nutrient Status in Apple cv. Royal Delicious
}

\author{
Shabber Hussain ${ }^{1 *}$, M.K. Sharma ${ }^{1}$, D. Bashir ${ }^{1}$, P. Tundup ${ }^{2}$, \\ S.A. Bangroo ${ }^{2}$ and A. Kumar ${ }^{1}$ \\ ${ }^{1}$ Department of Fruit Science, ${ }^{2}$ Department of Soil Science, Faculty of Horticulture, SKUAST- \\ K, Shalimar, J\&K-190025, India \\ *Corresponding author
}

A B S T R A C T

The present investigation entitled "Effect of orchard floor management practices on nutrient status in apple" was carried out on a 19-year-old trees in aprivate apple orchard at

Keywords

Apple, Mulching, Herbicides, Cover crop, Macro and micro nutrients

Article Info

Accepted:

24 January 2018

Available Online:

10 February 2018 village Arabal, District Srinagar during the years 2015 and 2016. Forty-five trees of uniform growth and vigour were selected for experimentation. The effects of fifteen orchard floor management practices were studied on apple cv. Royal Delicious. The treatments were replicated thrice in Factorial Randomized Complete Block Design. The results revealed that nutrient content of fruits as well as leaves were appreciably influenced by different treatments and highest level of both macro and micronutrients was recorded under paddy straw mulch followed by glyphosate. Maximum soil moisture was recorded under paddy straw mulch followed by glyphosate and maximum soil temperature was recorded under bicolour polythene mulch. With respect Benefit: cost ratio was highest with paddy straw mulch followed by glyphosate which was closely followed by cowpea (green manure). It can be concluded from the study that application of paddy straw mulch followed by glyphosate resulted in acceptable level of weed control with improved nutrient status apple fruit and leaves as well as good soil health hence can be recommended in apple orchards.

\section{Introduction}

Apple (Malusx domestica Borkh.) is produced commercially in most countries in temperate regions of the world and high altitude in some tropical areas. In India, apple is the most important temperate fruit crop of the north western Himalayan region especially Jammu and Kashmir, Himachal Pradesh and Uttarakhand due to its greater potential of favourable climatic conditions. Its primary centre of origin is south-western Asia, in the Caucasus region near Gilan in Turkestan and domesticated by Greeks and Romans and few centuries BC in Middle-East and Southeastern Europe as a result of their travel and invasions. In Jammu and Kashmir, apple has been grown as early as 2000 BC. M. Ermens, formerly Head Gardeners of Public Works in Paris, who came to Kashmir during 1865 brought with him a number of fruit plants which he believed would thrive in Kashmir 
together with implementations of starting in experimental agriculture farm. These fruit trees were planted in ChashmaShahi, near Srinagar, J\&K, in 1875 (Singh and Pal, 2013).

In India, apple occupies an area of 2,77,000 hectares with an annual production of $22,42,000$ metric tonnes and productivity of 8.0 MTha $^{-1}$ (Anonymous, 2016). The total apple growing area in Jammu and Kashmir is $1,62,971$ hectares with production of $17,26,834$ metric tonnes and productivity of 10.60 MT ha ${ }^{-1}$ (Anonymous, 2017) in which the contribution of Kashmir region is 97.78 per cent of total production from 88.87 per cent of total area.

The productivity of apple in India is very low as compared to developed countries like China, Italy, Spain, USA etc. The low average yields are primarily due to improper orchard management practices. Apple orchards are generally, infested with various types of annual, biennial and perennial weeds which compete with the fruit plants for nutrients, and moisture (Majek et al., 1993) and thereby directly reducing the productivity of fruit trees. Weeds also provide shelter to various pathogens by becoming an alternate orcollateral host of invaded crops by a number of fungal, bacterial and viral diseases. It has been reported that about 36-42 per cent losses may occur due to inadequate management of weeds in apple (El-Metwally and Hafez, 2007).

Although weed control in orchards is usually accomplished by various methods viz., manual, mechanical and chemical means, yet the conventional hand weeding is the most common method. Nevertheless, manual weed control is not only laborious but is also highly expensive. Thus of late, manual and mechanical weed control methods are gradually being replaced by other alternatives such as the use of mulches and herbicides as these are easier, cheaper and less time consuming. The ground management systems studies have shown substantially different effects on soil chemical, biological, and physical properties (Laurent et al., 2008) as well as differential effects on root-zone microbial communities and tree root development (Yao et al., 2005). Mulch assists in keeping the soil free from vegetation, conserves soil moisture, keeps temperature constant, increases organic matter through decomposition, releases nutrients to the soil, and improves the soil environment by enhancing microbial activity (Merwin et al., 1994; Marsh et al., 1996; Sanchez et al., 2003). Among the types of mulch that farmers can use are living mulches, polyethylene and geotextile mulches, and dead organic mulches such as straw, bark and loose materials. Living mulch is defined as a mixed cropping system, in which one partner acts chiefly as a live soil cover for a considerable part of the life cycle of the main crop (Liedgens et al., 2004). These kinds of mulches are well suited to use in fruit crops (Varadi et al., 1989 and Ingels et al., 1994) but even in established orchards living mulch growing along the planted row may depress crop growth (Domange, 1993 and Marks, 1993).

Clean cultivation is yet one of the common orchard floor management practice in plant basin during the growing season and leave therefore without any cultivation which increases soil erosion and cause moisture loss. Continuous, clean cultivation of the orchard floor aerates the soil and eliminates competition, but loss of organic matter, breakdown of soil structure, increased potential for erosion, and destruction of shallow tree roots will occur (Skroch and Shribbs, 1986; Hogue and Neilsen, 1987). Use of herbicides (pre and post emergence) reduce soil structure, fertility, and orchard productivity compared with "living" and straw-hay mulches (Merwin et al., 
1994).Conventional practices for weed management in orchards usually include annual application of residual herbicides in the inter-rows, as well as repeated use of glyphosate in the tree rows. Herbicides are considered excellent tools within a weed management strategy in many cropping systems; however, misuse of this technology can lead to problems such as residual carryover, cropping restrictions, groundwater contamination and the development of genetically-based herbicide resistance (Booth et al., 2003). Various herbicides such as atrazine, oxyflourfen, pendimethalin, simazine, glyphosate etc. have been reported to be very effective in controlling the weeds in different fruit orchards. The combination of mulches and herbicides holds promise as a method for long term control of weeds and reduce labor costs, concomitantly.

Weed management strategies for field production requires extensive knowledge of weed biology, herbicide application and calibration procedures, herbicide efficacy against target weeds and correct timing of application (Altland et al., 2003), the most common reasons for ineffectiveness of herbicides are improper timing, improper rates, and wrong selection of herbicide for the prevalent weed species. The use of green manure crops particularly legumes and cover crops such as white clover as soil management practices has also been found very effective in increasing the yield of fruit trees.

In apple orchards of Kashmir valley, the common floor management practice is to perform hoeing during March and May and leave thereafter without any cultivation. In the valley, winter and spring rains are followed by drought in summer months, so it becomes necessary to conserve available soil moisture of winter and spring season for growth and development during summer months. However, information on the use of different orchard floor management practices in apple cultivation is lacking in Jammu and Kashmir state. Therefore, present study was carried out to standardize best floor management practices for adoption in the agro-climatic condition of Jammu and Kashmir with the objectives of the effect of orchard floor management practices on soil health and nutrient status.

\section{Materials and Methods}

The present investigations entitled "Effect of orchard floor management practices on apple production" was carried out in a private apple orchard at village Arabal, District Srinagar, Jammu and Kashmir during the years 2015 and 2016. The details of materials used and the methods adopted during the course of investigation are given below.

\section{Geographical location of experimental site}

Kashmir is characterized by temperate climate. Winters are severe; extending from December to March and the temperatures often go below freezing point during this period. The valley is mostly covered with snow during the winter months. The altitude of Kashmir valley ranges between 1500-2500 meters above mean sea level. The mean maximum temperatures of the valley are $24.5^{\circ} \mathrm{C}$ and mean minimum temperature is $1.2^{\circ} \mathrm{C}$ with a relative humidity of 43.90 per cent. The normal precipitation is $650 \mathrm{~mm}$ mostly received during March-May. The experimental orchard is situated at an elevation of $1611 \mathrm{~m}$ above mean sea level and lies at $34^{\circ} 09^{\prime} \mathrm{N}$ latitude and $74^{\circ} 52^{\prime} \mathrm{E}$ longitude. During the experimentation period, the maximum average temperature was $20^{\circ} \mathrm{C}$ and $23^{\circ} \mathrm{C}$ and minimum mean temperature was $6^{\circ} \mathrm{C}$ and $8^{\circ} \mathrm{C}$ during 2015 and 2016, respectively. The total precipitation of 839 $\mathrm{mm}$ and $427 \mathrm{~mm}$ was received during entire experimental periods during 2015 and 2016. 


\section{Materials}

Nineteen-years-old bearing trees of apple cv. 'Royal Delicious' of uniform size and vigour receiving of uniform cultural practices were selected for the experimentation. Treatments and replications were randomly assigned with a single plot size.

\section{Experimental details}

The experiment was laid out on 19-years-old apple trees of cv. Royal Delicious spaced at 5 $\mathrm{m} \times 5 \mathrm{~m}$ in randomized complete block design with fifteen treatments. Each treatment was replicated thrice with respect to orchard floor management practices adopted during 2015 and 2016, which are given here as under:

\section{Field preparations}

Basins of experimental trees were properly levelled before conducting the experiment.

\section{Method and time of application}

\section{Mulches}

The application of mulches and sowing of white clover and cowpea were done during last week of March. Cowpea was incorporated in the soil seven weeks after sowing.

\section{Herbicides}

The commercial formulations of oxyflourfen, atrazine, pendimethalin and glyphosate herbicides were applied as directed spray with high volume of power Knapsack sprayer. Oxyflourfen, atrazine and pendimethalin were applied as pre-emergence herbicides during the last week of March, whereas, glyphosate was applied as post-emergence herbicide during last week of June. Weeding in zero weeds was done at frequent intervals while the weeding in clean cultivation was done at 30 days intervals throughout the course of studies.

\section{Active ingredient (a.i.)}

It is a part of chemical formulation which is directly responsible for herbicidal effect.

Thus, the commercial herbicide is made up of two parts i.e. the effective part and the inert part. Since all the recommendations are made on the basis of a.i., herbicides quantity was calculated with following formula:

Weight of herbicide required $\left(\mathrm{kg} \mathrm{ha}^{-1}\right.$ or $\left.1 \mathrm{t} \mathrm{ha}{ }^{-1}\right)=$

Dose of chemical required $\times 100$

Active Ingredient $\%$ in chemical product

\section{Fruit and leaf nutrient status}

Fruit samples (8 numbers in each treatment) were collected at harvest time, while leaf samples (40-50) were collected on 15 July 2015 and 2016. Both fruit and leaf samples were first washed with tap water followed by labolene wash and finally by distilled water to be dried on newspapers overnight and then transferred to oven for drying till constant weight at $60{ }^{\circ} \mathrm{C}$.

Then the samples were crushed in stainless steel blender and stored in polythene bags for analysis. Leaf samples from the experimental trees were collected from the mid-point of the current season's terminal growth during midJuly. After collection of leaf samples, the fresh leaves were thoroughly washed first with tap water, and then dipped in $0.1 \mathrm{~N} \mathrm{HCl}$ and then in distilled water. After air drying samples were dried in an oven at $60{ }^{\circ} \mathrm{C}$ till constant weight was obtained (Chapman, 1964). The dried leaves were ground in steel Willey mill and then kept in butter bags for chemical 
analysis. The procedures adopted for analysis of different nutrients are given below:

\section{Estimation of total nitrogen}

Total nitrogen was determined by Microkjeldahl method by involving digestion, distillation and titration of fruit and leaf samples as described by Jackson (1973).

Digestion and preparation of fruit and leaf samples to determine other nutrients except nitrogen

To estimate nutrient elements other than nitrogen viz. phosphorus, potassium, calcium, magnesium, sulphur, iron, manganese, zinc and copper, fruit and leaf samples were digested separately in diacid mixture of nitric acid and perchloric acid.

The digested material was diluted in double distilled water and filtered in $100 \mathrm{ml}$ volumetric flask. In order to ensure complete transfer of digested material, about six washings were given with double distilled water and final volume was made to $100 \mathrm{ml}$.

\section{Phosphorus}

Phosphorus content was estimated from digested samples by the Vanadomolybdate colour reaction method with the help of the Spectrophotometer (Jackson, 1973).

\section{Potassium}

Potassium content was determined using flame photometer (Jackson, 1973).

\section{Calcium and magnesium}

Calcium and magnesium contents were determined by versenate titration method (Jackson, 1973).

\section{Micronutrient cations}

The available (DTPA-extractable) micronutrients $(\mathrm{Zn}, \mathrm{Cu}, \mathrm{Fe}$ and $\mathrm{Mn})$ contents of fruit and leaves were determined in Atomic absorption spectrophotometry, as suggested by Lindsay and Norvell (1978).

\section{Soil parameters}

\section{Soil temperature $\left({ }^{0} \mathrm{C}\right)$ at $0-15 \mathrm{~cm}$}

Soil temperature $\left({ }^{\circ} \mathrm{C}\right)$ of each experimental treatment was recorded at depth of $0-15 \mathrm{~cm}$ with the help of digital soil thermometer. First reading was taken on $1^{\text {st }}$ April and subsequent readings at 15 days' intervals. Final reading was recorded at the time of harvesting.

\section{Soil moisture (\%) at $0-15 \mathrm{~cm}$}

Soil moisture was recorded at $0-15 \mathrm{~cm}$ depth by oven dry method and expressed in per cent $(\%)$.

\section{Results and Discussion}

Effect of orchard floor management practices on fruit macronutrient status

The data pertaining to fruit macronutrients $(\mathrm{N}$, $\mathrm{P}, \mathrm{K}, \mathrm{Ca}$ and $\mathrm{Mg}$ ) are given in Table 1.Significantly highest fruit nitrogen content (0.450 and $0.457 \%$ ) was recorded under paddy straw mulch followed by glyphosate, which was statistically at par with paddy straw mulch and cowpea. The phosphorous content in apple fruit $(0.109$ and $0.111 \%$ ) was maximum under paddy straw mulch followed by glyphosate, which was statistically at par with paddy straw mulch and cowpea viz. (0.108 and $0.109 \%)$ and $(0.107$ and $0.109 \%$, respectively. Minimum phosphorous content $(0.103$ and $0.101 \%$ ) was obtained in control. The potassium content of apple fruit was significantly affected with different 
treatments. Maximum total potassium content $(0.712$ and $0.716 \%)$ was recorded under paddy straw mulch followed by glyphosate and minimum phosphorous content (0.694 and $0.693 \%$ ) was observed with unweeded control. Markedly higher fruit calcium (0.173 and $0.179 \%$ ) and magnesium (0.017 and $0.019 \%$ ) content was recorded under paddy straw mulch followed by glyphosate. However minimum fruit calcium and magnesium content $(0.124$ and $0.122 \%)$ and $(0.010 \%)$ was observed under unweeded control.

The use of mulch materials and herbicides reduced the competition for nutrient and moisture thus resulting in more availability of water supply and ultimately more uptake of nutrient by the tree (Raese, 1990). Present results are also in conformation with the finding of Copper(1973) who reported that mulches provide many benefit to crop production through moisture conservation, enhanced soil microbial activities and improved chemical and physical properties of the soil. Similarly, Lakatos et al., (2001) reported that microbial activities play a significant part in the availability and transformation of minerals like calcium, magnesium, and will therefore influence plant nutrition availability, and also announced that mulching significantly reduced the incidence of bitter pit due to improved calcium nutrition. Szewczuk and Gudarowska (2004) also found that mulching with both organic and inorganic material, increased fruit Ca concentration.

\section{Effect of orchard floor management practices on leaf macronutrient and micronutrient status}

\section{Leaf macronutrients}

\section{Leaf nitrogen}

The data pertaining to leaf macronutrients $(\mathrm{N}$, $\mathrm{P}, \mathrm{K}, \mathrm{Ca}$ and $\mathrm{Mg}$ ) and micronutrients $(\mathrm{Zn}, \mathrm{Cu}$,
Fe and Mn) status of Royal Delicious apple as influenced by various orchard floor management practices during 2015 and 2016 are presented in Tables 2 and 3, respectively. In the present studies, leaf nitrogen content (2.419 and $2.427 \%$ ) was maximum under paddy straw mulch followed by glyphosate. However minimum leaf nitrogen content was recorded under control (2.347 and $2.345 \%$ ). These results are in accordance with the findings of Meena et al., (2015) and Negi (2015) who reported significantly higher leaf nitrogen with grass mulch followed by glyphosate. Similar results were also reported by Shylla et al., (1999) in plum who reported that leaf nutrients were significantly influenced by different orchard floor management practices. The glyphosate herbicide treatment significantly increased the leaf nitrogen content, closely followed by green manuring. The use of herbicides and mulch material reduced the competition for nutrients and moisture, resulting in greater availability of nutrients. Similar results were also reported by Neilson et al., (1982).

The increase in leaf $\mathrm{N}$ may be due to higher temperature, moisture and organic carbon content which increased the biological activities under grass mulching possibly resulted in fast mineralization and nitrogen availability and high translocation of nitrogen from soil to the leaves (Negi, 2015 and Schutt et al., 2014).

Bhat and Khokhar (2009) and Sas-Paszt et al., (2014) also reported that grass mulch significantly increased leaf $\mathrm{N}$ content. Mulches from different organic materials with variable properties have different effects on the soil food web, as well as the mineralization of the elements such as $\mathrm{N}$ and $\mathrm{P}$ as reported by Forge et al., (2003). The results of the study are also in close conformity with the earlier findings of Das et al., (2016) in litchi. 


\section{Leaf phosphorous and potassium}

Leaf phosphorous and potassium contents showed appreciable variation among different treatments. Maximum leaf phosphorous content $(0.300$ and $0.303 \%)$ and potassium content (1.803 and $1.823 \%$ ) was recorded with paddy straw mulch followed by glyphosate, which was statistically at par with paddy straw mulch and cowpea. However minimum phosphorous and potassium contents were observed with unweeded control. The results are in conformity with the finding of Meena (2013) and Negi (2015) who reported maximum leaf phosphorous and potassium contents under pendimethalin followed by glyphosate due to reduced weed competition. These findings are also in agreement with Shylla and Chauhan (2004) who observed highest nutrients in plum trees intercropped with French bean. Hoagland et al., (2008) also noticed highest leaf phosphorus contents in cherry trees intercropped with red clover which might be due to the fact that red clover or other legumes improve soil physical conditions thereby facilitates more nutrient uptake.

\section{Leaf calcium and magnesium}

Highest leaf calcium (1.752 and $1.785 \%)$ and magnesium $(0.312$ and $0.318 \%)$ contents were recorded in apple trees mulched with paddy straw mulch followed by glyphosate and was statistically at par with paddy straw mulch and cowpea and lowest calcium and magnesium were recorded in unweeded control. This finding is in consonance with the observation of Kumar (1984) who reported higher Ca and $\mathrm{Mg}$ contents of leaves in mulching plus herbicides treated plum trees due to better availability of moisture in the soil. The results are also in conformity with Hoagland et al., (2008) who noticed mobilization of calcium and magnesium by legume covers in cherry rhizosphere. Similar findings were also reported by Shylla and Chauhan (2004) in plum and Wani et al., (2013) in cherry, who observed highest nutrients in trees intercropped with leguminous crops.

\section{Leaf micronutrients}

\section{Leaf zinc}

Significantly higher leaf zinc content (51.58 and $52.07 \mathrm{ppm}$ ) was obtained with paddy straw mulch followed by glyphosate $\left(\mathrm{T}_{10}\right)$, which was statistically at par with paddy straw mulch (51.28 and 52.02 ppm) and cowpea(48.96 and $49.95 \mathrm{ppm})$. Unweeded control had minimum leaf zinc content (40.84 and $40.80 \mathrm{ppm}$ ) which was at par with atrazine and pendimethalin during 2015 and 2016.

\section{Leaf iron}

Perusal of the data presented in Table 3 revealed that different weed control treatments exerted a significant influence on leaf iron content. During 2015 and 2016 treatment paddy straw mulch followed by glyphosate $\left(\mathrm{T}_{10}\right)$ recorded highest leaf iron content (222.9 and $223.4 \mathrm{ppm}$ ) which was statistically at par with paddy straw mulch and cowpea. However minimum leaf iron content (215.0 and $215.4 \mathrm{ppm}$ ) was recorded in unweeded control during both the years of study.

\section{Leaf copper}

Different orchard floor management practices significantly influence leaf copper content during both the years of study (Table 3). Maximum leaf copper content (14.05 and $14.19 \mathrm{ppm}$ ) was recorded with paddy straw mulch followed by glyphosate $\left(\mathrm{T}_{10}\right)$, which was statistically at par with paddy straw mulch, cowpea and bicolour polythene mulch. The unweeded control recorded minimum leaf copper content (11.73 and $11.71 \mathrm{ppm}$ ) during both the years of study. 


\section{Leaf manganese}

All the orchard floor management practices showed significant effect on leaf manganese content during 2015 and 2016 (Table 3). Paddy straw mulch followed by glyphosate $\left(\mathrm{T}_{10}\right)$ recorded highest value of leaf manganese content (104.2 and $105.5 \mathrm{ppm})$ which was statistically at par with the paddy straw mulch (103.7 and $105.0 \mathrm{ppm}$ ), cowpea (103.3 and $105.0 \mathrm{ppm}$ ) during 2015 and oxyflourfene followed by glyphosate (103.7 ppm) during 2016. Unweeded control registered lowest leaf manganese content to the tune of 98.9 and $99.0 \mathrm{ppm}$ during both the years of study.

Leaf $\mathrm{Zn}, \mathrm{Fe}, \mathrm{Cu}$ and $\mathrm{Mn}$ contents were significantly increased with different orchard floor management practices. Maximum micronutrients content of leaves was recorded under paddy straw mulch followed by glyphosate, which was statistically at par with treatments paddy straw mulch and cowpea. All the micronutrient content in leaves increased marginally over the year. These nutrients were found in normal range as established by Shear and Faust (1980). Mulches registered highest value of foliar $\mathrm{Cu}$, $\mathrm{Fe}$ and $\mathrm{Mn}$ content and were lowest in control. The use of mulch materials and herbicides reduced the competition for nutrients and moisture thus resulting in more availability of moisture and ultimately more uptake of nutrient by the tree. The integrated use of mulch materials with herbicides has additional benefit of checking moisture loss through evaporation from the soil. Mulches also add organic matter to the soil thus increasing the nutrient status in soil solution. Similar responses have been reported by Shylla et al., (1999). The observations are also in close conformity with the finding of Negi (2015) who reported maximum micro nutrient contents under different mulch treatments. Yin et al., (2007) reported increased foliar nutrient status with polypropylene cover relative to no cover during the 5-year trial in cherry while Merwinet al., (1995) with hay in apple and Wheeler et al., (1999) with grass clippings in pecan trees. There was a significant effect of ground covers on leaf $\mathrm{Mn}$ concentration, because soil Mn availability increases with decreasing pH (Neilsen and Neilsen, 2003 and Houge et al., 2010). Sas-Paszt et al., (2014) also reported increased leaf $\mathrm{Cu}, \mathrm{Fe}$, and $\mathrm{Mn}$ with straw mulches.

The results obtained in present investigation are also in line with the finding of Bhat and Khokhar (2009) who reported that grass mulch, though at par with pine needles mulch, grass mulch followed by atrazine and grass mulch followed by oxyfluorfen treatments, significantly increased the leaf $\mathrm{Fe}, \mathrm{Cu}, \mathrm{Zn}$ and $\mathrm{B}$ contents over other treatments, inducing hand weeding control which recorded minimum leaf nutrient status but the effect on Mn was found to be non-significant.

\section{Effect of orchard floor management practices on soil moisture and temperature}

Observations pertaining to soil moisture and soil temperature following the use of different orchard floor management practices were studied during 2015 and 2016.

\section{Soil moisture}

Different orchard floor management practices had a significant influence on per cent soil moisture content at $0-15 \mathrm{~cm}$ depth during both the years of study. Data presented in Table 4 revealed that during 2015 treatment paddy straw mulch followed by glyphosate $\left(\mathrm{T}_{10}\right)$ recorded highest soil moisture content $(26.16 \%)$ which was statistically at par with paddy straw mulch $(26.12 \%)$ followed by bicolour polythene mulch $(25.19 \%)$. Among different days of observation, the maximum soil moisture content $(26.24 \%)$ was recorded on 105 days after treatment. 
Table.1 Effect of orchard floor management practices on fruit macronutrient status of apple cv. Royal Delicious during 2015 and 2016

\begin{tabular}{|c|c|c|c|c|c|c|c|c|c|c|c|}
\hline \multicolumn{2}{|r|}{ Treatments } & \multicolumn{2}{|c|}{$\mathbf{N}(\%)$} & \multicolumn{2}{|c|}{$\mathbf{P}(\%)$} & \multicolumn{2}{|c|}{$\mathbf{K}(\%)$} & \multicolumn{2}{|c|}{$\mathrm{Ca}(\%)$} & \multicolumn{2}{|c|}{$\operatorname{Mg}(\%)$} \\
\hline & & 2015 & 2016 & 2015 & 2016 & 2015 & 2016 & 2015 & 2016 & 2015 & 2016 \\
\hline $\mathbf{T}_{1}$ & Control (no weeding) & 0.408 & 0.405 & 0.103 & 0.101 & 0.694 & 0.693 & 0.124 & 0.122 & 0.010 & 0.010 \\
\hline $\mathbf{T}_{2}$ & Farmer practices (Hoeing during March and May) & 0.423 & 0.423 & 0.104 & 0.105 & 0.701 & 0.702 & 0.129 & 0.135 & 0.012 & 0.012 \\
\hline $\mathbf{T}_{3}$ & Zero weeds (weeding at frequent intervals) & 0.430 & 0.436 & 0.105 & 0.108 & 0.703 & 0.705 & 0.139 & 0.149 & 0.014 & 0.013 \\
\hline $\mathbf{T}_{4}$ & Clean cultivation (weeding at 30 days interval) & 0.427 & 0.434 & 0.105 & 0.107 & 0.703 & 0.704 & 0.142 & 0.147 & 0.013 & 0.013 \\
\hline $\mathbf{T}_{5}$ & Bicolour polythene mulch $(250 \mu \mathrm{m})$ & 0.442 & 0.443 & 0.107 & 0.108 & 0.708 & 0.710 & 0.160 & 0.170 & 0.014 & 0.015 \\
\hline $\mathbf{T}_{6}$ & Paddy straw mulch (10 cm thick) & 0.448 & 0.455 & 0.108 & 0.109 & 0.710 & 0.713 & 0.170 & 0.177 & 0.016 & 0.018 \\
\hline $\mathbf{T}_{7}$ & Oxyflourfen@1.01ha ${ }^{-1}$ (pre-emergence) & 0.411 & 0.414 & 0.104 & 0.105 & 0.700 & 0.701 & 0.128 & 0.136 & 0.011 & 0.011 \\
\hline $\mathbf{T}_{8}$ & Atrazine@3.0 kg ha ${ }^{-1}$ (pre-emergence) & 0.409 & 0.411 & 0.104 & 0.103 & 0.695 & 0.695 & 0.125 & 0.128 & 0.010 & 0.010 \\
\hline $\mathbf{T}_{9}$ & Pendimethalin@2.01ha ${ }^{-1}$ (pre-emergence) & 0.411 & 0.412 & 0.104 & 0.104 & 0.697 & 0.698 & 0.124 & 0.128 & 0.010 & 0.011 \\
\hline $\mathbf{T}_{10}$ & $\begin{array}{l}\text { Paddy straw mulch }(10 \mathrm{~cm} \text { thick) followed by } \\
\text { glyphosate @ } 2.01 \mathrm{ha}^{-1} \text { (post-emergence) }\end{array}$ & 0.450 & 0.457 & 0.109 & 0.111 & 0.712 & 0.716 & 0.173 & 0.179 & 0.017 & 0.019 \\
\hline $\mathbf{T}_{11}$ & $\begin{array}{l}\text { Oxyflourfen } \\
\text { followed by } \\
\text { emergence) }\end{array}$ & 0.441 & 0.445 & 0.106 & 0.108 & 0.706 & 0.708 & 0.155 & 0.157 & 0.014 & 0.016 \\
\hline $\mathbf{T}_{12}$ & $\begin{array}{l}\text { Atrazine@3.0 kg ha-1 (pre-emergence) followed } \\
\text { by glyphosate@ } 2.01 \mathrm{ha}^{-1} \text { (post-emergence) }\end{array}$ & 0.435 & 0.439 & 0.106 & 0.107 & 0.702 & 0.704 & 0.149 & 0.152 & 0.013 & 0.015 \\
\hline $\mathbf{T}_{13}$ & $\begin{array}{l}\text { Pendimethalin @ } 2.01 \mathrm{ha}^{-1} \text { (pre-emergence) } \\
\text { followed by glyphosate @ } 2.01 \mathrm{ha}^{-1} \text { (post- } \\
\text { emergence) }\end{array}$ & 0.436 & 0.442 & 0.106 & 0.107 & 0.703 & 0.706 & 0.147 & 0.157 & 0.014 & 0.015 \\
\hline $\mathbf{T}_{14}$ & Cowpea (green manure) & 0.446 & 0.453 & 0.107 & 0.109 & 0.709 & 0.713 & 0.164 & 0.173 & 0.016 & 0.019 \\
\hline $\mathbf{T}_{15}$ & White clover (cover crop) & 0.433 & 0.441 & 0.105 & 0.108 & 0.706 & 0.708 & 0.142 & 0.152 & 0.014 & 0.016 \\
\hline & C.D. $(p \leq 0.05)$ & 0.013 & 0.018 & NS & 0.003 & 0.005 & 0.005 & 0.016 & 0.020 & 0.002 & 0.002 \\
\hline
\end{tabular}


Table.2 Effect of orchard floor management practices on leaf macro nutrient content (\%) of apple cv. Royal Delicious during 2015 and 2016

\begin{tabular}{|c|c|c|c|c|c|c|c|c|c|c|c|}
\hline \multirow{2}{*}{\multicolumn{2}{|c|}{ Treatments }} & \multicolumn{2}{|c|}{$\mathbf{N}(\%)$} & \multicolumn{2}{|c|}{$\mathbf{P}(\%)$} & \multicolumn{2}{|c|}{$\mathbf{K}(\%)$} & \multicolumn{2}{|c|}{$\mathrm{Ca}(\%)$} & \multicolumn{2}{|c|}{$\operatorname{Mg}(\%)$} \\
\hline & & 2015 & 2016 & 2015 & 2016 & 2015 & 2016 & 2015 & 2016 & 2015 & 2016 \\
\hline $\mathbf{T}_{1}$ & Control (no weeding) & 2.347 & 2.345 & 0.267 & 0.267 & 1.735 & 1.738 & 1.533 & 1.530 & 0.280 & 0.280 \\
\hline $\mathbf{T}_{2}$ & Farmer practices (Hoeing during March and May) & 2.394 & 2.399 & 0.272 & 0.278 & 1.758 & 1.764 & 1.570 & 1.636 & 0.293 & 0.295 \\
\hline $\mathbf{T}_{\mathbf{3}}$ & Zero weeds (weeding at frequent intervals) & 2.400 & 2.408 & 0.278 & 0.286 & 1.775 & 1.780 & 1.650 & 1.700 & 0.300 & 0.305 \\
\hline $\mathbf{T}_{4}$ & Clean cultivation (weeding at 30 days interval) & 2.400 & 2.404 & 0.275 & 0.283 & 1.773 & 1.778 & 1.597 & 1.549 & 0.298 & 0.303 \\
\hline $\mathbf{T}_{\mathbf{5}}$ & Bicolour polythene mulch $(250 \mu \mathrm{m})$ & 2.408 & 2.413 & 0.289 & 0.290 & 1.777 & 1.785 & 1.730 & 1.740 & 0.305 & 0.306 \\
\hline $\mathbf{T}_{6}$ & Paddy straw mulch (10 cm thick) & 2.414 & 2.420 & 0.297 & 0.300 & 1.797 & 1.815 & 1.743 & 1.759 & 0.310 & 0.315 \\
\hline $\mathbf{T}_{7}$ & Oxyflourfen@1.01 ha ${ }^{-1}$ (pre-emergence) & 2.353 & 2.358 & 0.270 & 0.273 & 1.750 & 1.761 & 1.570 & 1.600 & 0.293 & 0.295 \\
\hline $\mathbf{T}_{8}$ & Atrazine @3.0 kg ha ${ }^{-1}$ (pre-emergence) & 2.351 & 2.355 & 0.270 & 0.272 & 1.743 & 1.748 & 1.541 & 1.564 & 0.285 & 0.287 \\
\hline $\mathbf{T}_{9}$ & Pendimethalin@2.01 ha ${ }^{-1}$ (pre-emergence) & 2.351 & 2.358 & 0.268 & 0.272 & 1.743 & 1.751 & 1.557 & 1.568 & 0.285 & 0.290 \\
\hline $\mathbf{T}_{10}$ & $\begin{array}{l}\text { Paddy straw mulch }(10 \mathrm{~cm} \text { thick) followed by } \\
\text { glyphosate @ } 2.01 \mathrm{ha}^{-1} \text { (post-emergence) }\end{array}$ & 2.419 & 2.427 & 0.300 & 0.303 & 1.803 & 1.823 & 1.757 & 1.785 & 0.312 & 0.318 \\
\hline $\mathbf{T}_{11}$ & $\begin{array}{l}\text { Oxyflourfen } \\
\text { followed by } \\
\text { emergence) }\end{array}$ & 2.405 & 2.413 & 0.279 & 0.283 & 1.770 & 1.793 & 1.705 & 1.733 & 0.302 & 0.309 \\
\hline$T_{12}$ & $\begin{array}{l}\text { Atrazine@3.0 kg ha-1 (pre-emergence) followed } \\
\text { by glyphosate@ } 2.01 \mathrm{ha}^{-1} \text { (post-emergence) }\end{array}$ & 2.402 & 2.408 & 0.275 & 0.282 & 1.768 & 1.780 & 1.690 & 1.722 & 0.295 & 0.303 \\
\hline $\mathbf{T}_{13}$ & $\begin{array}{l}\text { Pendimethalin @ } 2.01 \mathrm{ha}^{-1} \text { (pre-emergence) } \\
\text { followed by glyphosate @ } 2.01 \mathrm{ha}^{-1} \text { (post- } \\
\text { emergence) }\end{array}$ & 2.403 & 2.410 & 0.279 & 0.283 & 1.768 & 1.785 & 1.709 & 1.727 & 0.295 & 0.300 \\
\hline $\mathrm{T}_{14}$ & Cowpea (green manure) & 2.413 & 2.420 & 0.284 & 0.295 & 1.789 & 1.811 & 1.733 & 1.753 & 0.308 & 0.315 \\
\hline $\mathbf{T}_{15}$ & White clover (cover crop) & 2.408 & 2.416 & 0.284 & 0.291 & 1.779 & 1.800 & 1.730 & 1.747 & 0.306 & 0.308 \\
\hline & C.D. $(p \leq 0.05)$ & 0.008 & 0.015 & NS & 0.013 & 0.026 & 0.029 & 0.025 & 0.035 & NS & 0.005 \\
\hline
\end{tabular}


Table.3 Effect of orchard floor management practices on leaf micronutrient status of apple cv. Royal Delicious during 2015 and 2016

\begin{tabular}{|c|c|c|c|c|c|c|c|c|c|}
\hline \multirow{2}{*}{\multicolumn{2}{|c|}{ Treatments }} & \multicolumn{2}{|c|}{ Zn(ppm) } & \multicolumn{2}{|c|}{$\mathrm{Fe}(\mathrm{ppm})$} & \multicolumn{2}{|c|}{$\mathrm{Cu}(\mathrm{ppm})$} & \multicolumn{2}{|c|}{$\operatorname{Mn}(\mathbf{p p m})$} \\
\hline & & 2015 & 2016 & 2015 & 2016 & 2015 & 2016 & 2015 & 2016 \\
\hline $\mathbf{T}_{1}$ & Control (no weeding) & 40.84 & 40.80 & 215.0 & 215.4 & 11.73 & 11.71 & 98.9 & 99.0 \\
\hline $\mathbf{T}_{2}$ & Farmer practices (Hoeing during March and May) & 44.03 & 44.67 & 216.4 & 217.0 & 12.25 & 12.34 & 101.7 & 102.2 \\
\hline $\mathbf{T}_{3}$ & Zero weeds (weeding at frequent intervals) & 45.79 & 46.02 & 217.0 & 217.8 & 12.91 & 12.57 & 101.3 & 101.9 \\
\hline $\mathbf{T}_{4}$ & Clean cultivation (weeding at 30 days interval) & 45.17 & 45.64 & 216.5 & 217.1 & 12.62 & 12.70 & 100.9 & 101.5 \\
\hline $\mathbf{T}_{5}$ & Bicolour polythene mulch $(250 \mu \mathrm{m})$ & 47.85 & 48.32 & 220.8 & 221.5 & 13.90 & 14.00 & 102.8 & 103.3 \\
\hline $\mathbf{T}_{6}$ & Paddy straw mulch (10 cm thick) & 51.28 & 52.02 & 222.7 & 223.4 & 14.03 & 14.16 & 103.7 & 105.0 \\
\hline $\mathbf{T}_{7}$ & Oxyflourfen@1.01 ha ${ }^{-1}$ (pre-emergence) & 44.01 & 44.54 & 215.7 & 216.9 & 12.20 & 12.28 & 100.3 & 100.6 \\
\hline $\mathbf{T}_{8}$ & Atrazine@3.0 kg ha ${ }^{-1}$ (pre-emergence) & 42.38 & 42.88 & 215.3 & 215.9 & 11.89 & 11.90 & 99.3 & 99.9 \\
\hline $\mathbf{T}_{9}$ & Pendimethalin@2.01ha ${ }^{-1}$ (pre-emergence) & 43.07 & 43.63 & 216.3 & 216.5 & 11.99 & 12.04 & 101.0 & 100.4 \\
\hline $\mathbf{T}_{10}$ & $\begin{array}{l}\text { Paddy straw mulch }(10 \mathrm{~cm} \text { thick) followed by glyphosate @ } 2.01 \\
\text { ha }^{-1} \text { (post-emergence) }\end{array}$ & 51.58 & 52.07 & 222.9 & 223.4 & 14.05 & 14.19 & 104.2 & 105.5 \\
\hline $\mathbf{T}_{11}$ & $\begin{array}{l}\text { Oxyflourfen @1.01 ha }{ }^{-1} \text { (pre-emergence) followed by glyphosate } \\
\text { @ } 2.01 \text { ha }^{-1} \text { (post-emergence) }\end{array}$ & 46.71 & 47.31 & 219.4 & 220.0 & 13.66 & 13.74 & 103.1 & 103.7 \\
\hline $\mathbf{T}_{12}$ & $\begin{array}{l}\text { Atrazine @ } 3.0 \mathrm{~kg} \mathrm{ha}^{-1} \text { (pre-emergence) followed by glyphosate } \\
@ 2.01 \mathrm{ha}^{-1} \text { (post-emergence) }\end{array}$ & 46.25 & 46.82 & 218.7 & 219.5 & 13.28 & 13.46 & 101.4 & 102.0 \\
\hline $\mathbf{T}_{13}$ & $\begin{array}{l}\text { Pendimethalin @ } 2.0 \quad 1 \text { ha }^{-1} \text { (pre-emergence) followed by } \\
\text { glyphosate @ } 2.01 \mathrm{lha}^{-1} \text { (post-emergence) }\end{array}$ & 46.58 & 47.05 & 218.5 & 219.3 & 13.32 & 13.52 & 102.7 & 103.0 \\
\hline $\mathbf{T}_{14}$ & Cowpea (green manure) & 48.96 & 49.95 & 222.0 & 222.7 & 14.01 & 14.11 & 103.3 & 105.0 \\
\hline $\mathbf{T}_{\mathbf{1 5}}$ & White clover (cover crop) & 47.79 & 48.09 & 219.9 & 221.6 & 13.58 & 13.95 & 102.3 & 103.3 \\
\hline & C.D. $(p \leq 0.05)$ & 3.75 & 3.90 & 2.70 & 2.93 & 0.21 & 0.21 & 1.20 & 1.80 \\
\hline
\end{tabular}


Table.4 Effect of orchard floor management practices on soil moisture (\%) at 0-15 cm depth (15 days interval) of apple cv. Royal Delicious during 2015

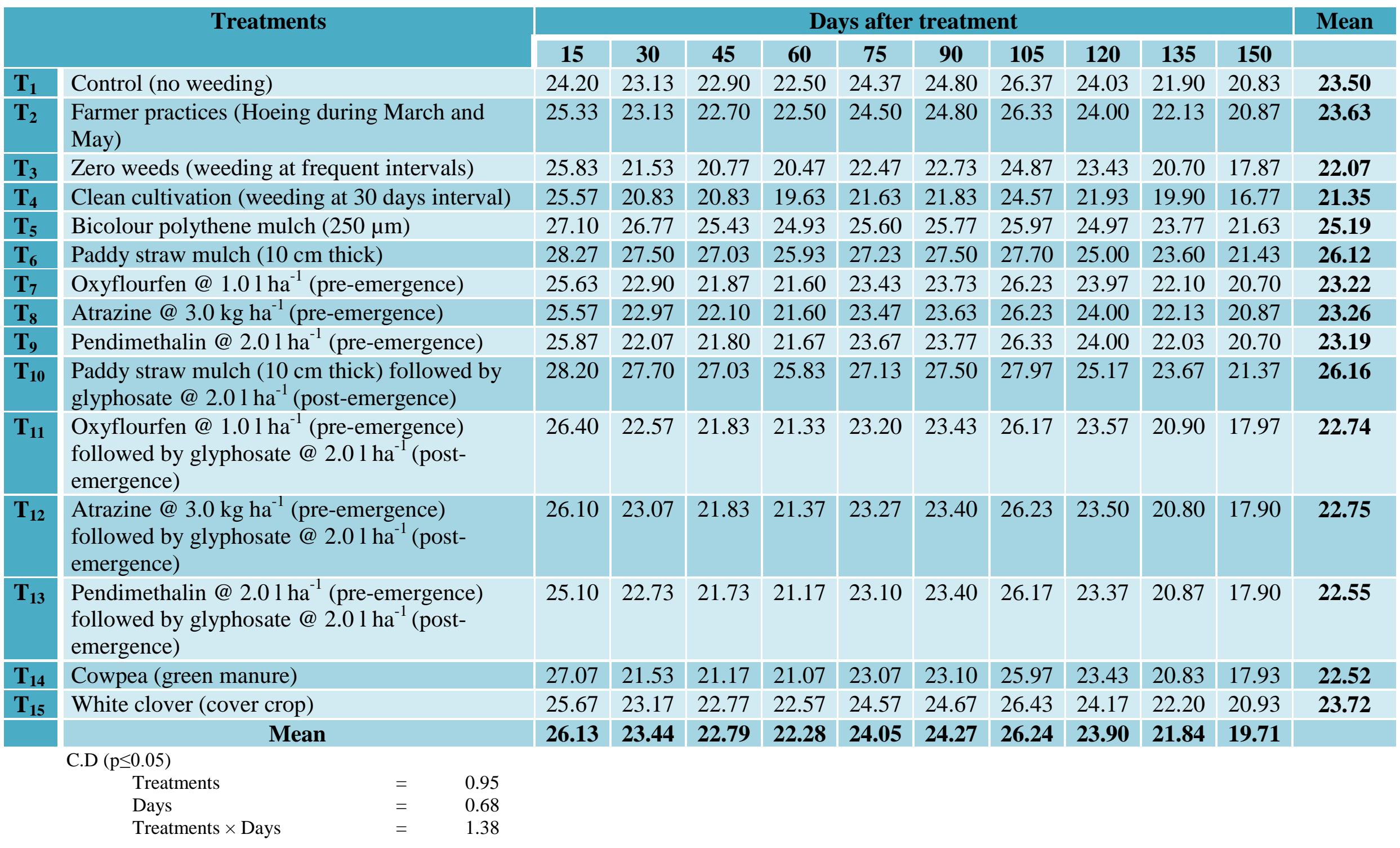


Table.5 Effect of orchard floor management practices on soil moisture (\%) at 0-15 cm depth (15 days interval) of apple cv. Royal Delicious during 2016

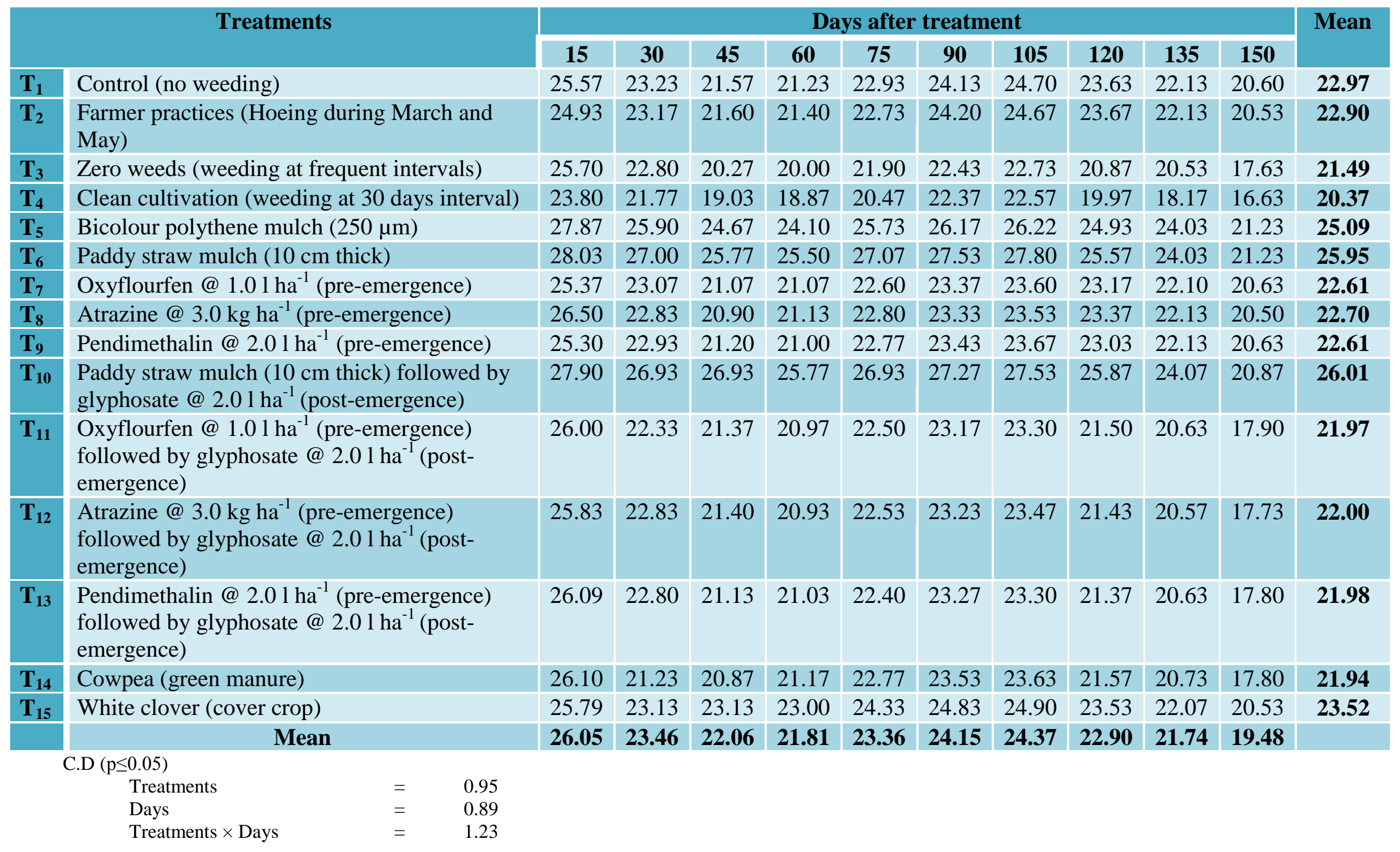


Table.6 Effect of orchard floor management practices on soil temperature $\left({ }^{\circ} \mathrm{C}\right)$ at $0-15 \mathrm{~cm}$ depth (15 days interval) of apple cv. Royal delicious during 2015

\begin{tabular}{|c|c|c|c|c|c|c|c|c|c|c|c|c|}
\hline \multirow{2}{*}{\multicolumn{2}{|c|}{ Treatments }} & \multicolumn{10}{|c|}{ Days after treatment } & \multirow{2}{*}{$\begin{array}{c}\text { Mea } \\
\text { n }\end{array}$} \\
\hline & & 15 & 30 & 45 & 60 & 75 & 90 & 105 & 120 & 135 & 150 & \\
\hline $\mathbf{T}_{1}$ & Control (no weeding) & 14.7 & 15.9 & 18.9 & 18.0 & 18.5 & 21.9 & 21.5 & 21.5 & 20.8 & 19.8 & 19.2 \\
\hline$T_{2}$ & $\begin{array}{l}\text { Farmer practices (Hoeing during March and } \\
\text { May) }\end{array}$ & 14.7 & 15.4 & 18.8 & 18.3 & 18.7 & 22.5 & 22.3 & 21.7 & 20.3 & 19.5 & 19.2 \\
\hline $\mathbf{T}_{3}$ & Zero weeds (weeding at frequent intervals) & 14.9 & 16.6 & 19.9 & 18.6 & 19.0 & 22.9 & 23.0 & 21.6 & 21.2 & 20.5 & 19.8 \\
\hline $\mathbf{T}_{4}$ & Clean cultivation (weeding at 30 days interval) & 14.9 & 16.7 & 20.1 & 18.9 & 19.2 & 22.2 & 22.4 & 21.9 & 21.3 & 20.6 & 19.8 \\
\hline$T_{5}$ & Bicolour polythene mulch $(250 \mu \mathrm{m})$ & 15.3 & 17.4 & 20.9 & 19.7 & 19.9 & 23.8 & 23.6 & 22.4 & 23.6 & 22.4 & 20.9 \\
\hline $\mathbf{T}_{6}$ & Paddy straw mulch (10 cm thick) & 14.2 & 15.0 & 19.3 & 17.0 & 18.0 & 21.5 & 22.3 & 22.0 & 21.2 & 20.3 & 19.1 \\
\hline $\mathbf{T}_{7}$ & Oxyflourfen@1.01 ha ${ }^{-1}$ (pre-emergence) & 14.0 & 15.4 & 20.0 & 19.0 & 19.2 & 22.5 & 22.2 & 21.9 & 20.4 & 19.7 & 19.4 \\
\hline $\mathbf{T}_{8}$ & Atrazine@3.0 kg ha ${ }^{-1}$ (pre-emergence) & 14.8 & 15.6 & 19.3 & 18.1 & 18.2 & 21.5 & 21.4 & 20.9 & 20.9 & 20.3 & 19.1 \\
\hline $\mathbf{T}_{9}$ & Pendimethalin@2.01 ha ${ }^{-1}$ (pre-emergence) & 14.9 & 15.4 & 20.0 & 18.4 & 18.5 & 22.0 & 21.8 & 21.1 & 20.9 & 20.1 & 19.3 \\
\hline $\mathbf{T}_{10}$ & $\begin{array}{l}\text { Paddy straw mulch }(10 \mathrm{~cm} \text { thick) followed by } \\
\text { glyphosate @ } 2.01 \text { ha }^{-1} \text { (post-emergence) }\end{array}$ & 14.4 & 15.5 & 19.1 & 17.7 & 18.3 & 21.4 & 21.6 & 21.3 & 21.1 & 20.2 & 19.1 \\
\hline $\mathbf{T}_{11}$ & $\begin{array}{l}\text { Oxyflourfen@1.01 ha }{ }^{-1} \text { (pre-emergence) } \\
\text { followed by glyphosate @ } 2.01 \mathrm{ha}^{-1} \text { (post- } \\
\text { emergence) }\end{array}$ & 14.8 & 16.2 & 20.1 & 18.9 & 19.1 & 22.1 & 22.1 & 21.6 & 21.2 & 20.3 & 19.6 \\
\hline $\mathbf{T}_{12}$ & $\begin{array}{l}\text { Atrazine @ } 3.0 \mathrm{~kg} \mathrm{ha}^{-1} \text { (pre-emergence) } \\
\text { followed by glyphosate @ } 2.01 \text { ha }^{-1} \text { (post- } \\
\text { emergence) }\end{array}$ & 14.3 & 16.4 & 20.1 & 18.5 & 18.9 & 22.3 & 22.4 & 21.8 & 21.1 & 20.3 & 19.6 \\
\hline $\mathbf{T}_{13}$ & $\begin{array}{l}\text { Pendimethalin @2.01 ha }{ }^{-1} \text { (pre-emergence) } \\
\text { followed by glyphosate @ } 2.01 \text { ha }^{-1} \text { (post- } \\
\text { emergence) }\end{array}$ & 14.1 & 16.1 & 20.0 & 18.7 & 19.0 & 22.8 & 22.9 & 21.7 & 21.1 & 20.3 & 19.7 \\
\hline $\mathbf{T}_{14}$ & Cowpea (green manure) & 14.5 & 15.9 & 20.1 & 18.4 & 19.2 & 22.4 & 22.0 & 21.7 & 20.8 & 19.8 & 19.5 \\
\hline $\mathbf{T}_{15}$ & White clover (cover crop) & 14.8 & 15.6 & 18.9 & 17.8 & 18.8 & 21.9 & 22.5 & 21.8 & 20.4 & 19.2 & 19.2 \\
\hline & Mean & 14.6 & 15.9 & 19.7 & 18.4 & 18.8 & 22.2 & 22.3 & 21.7 & 21.1 & 20.2 & \\
\hline & $\begin{array}{l}05) \\
\text { reatmen }\end{array}$ & & & & & & & & & & & \\
\hline & Days & & & & & & & & & & & \\
\hline & Treatments $\times$ Days & & & & & & & & & & & \\
\hline
\end{tabular}


Table.7 Effect of orchard floor management practices on soil temperature $\left({ }^{\circ} \mathrm{C}\right)$ at $0-15 \mathrm{~cm}$ depth (15 days interval) of apple cv. Royal Delicious during 2016

\begin{tabular}{|c|c|c|c|c|c|c|c|c|c|c|c|c|}
\hline \multirow{2}{*}{\multicolumn{2}{|c|}{ Treatments }} & \multicolumn{10}{|c|}{ Days after treatment } & \multirow{2}{*}{$\begin{array}{c}\text { Mea } \\
\text { n }\end{array}$} \\
\hline & & 15 & 30 & 45 & 60 & 75 & 90 & 105 & 120 & 135 & 150 & \\
\hline $\mathbf{T}_{1}$ & Control (no weeding) & 14.5 & 17.8 & 19.5 & 22.8 & 22.5 & 22.0 & 21.6 & 21.7 & 19.9 & 20.0 & 20.2 \\
\hline $\mathbf{T}_{2}$ & $\begin{array}{l}\text { Farmer practices (Hoeing during March and } \\
\text { May) }\end{array}$ & 14.5 & 17.4 & 19.7 & 22.3 & 22.4 & 22.3 & 22.6 & 21.7 & 19.6 & 19.9 & 20.2 \\
\hline $\mathbf{T}_{3}$ & Zero weeds (weeding at frequent intervals) & 14.7 & 17.6 & 19.9 & 22.6 & 22.7 & 22.8 & 23.1 & 21.7 & 20.6 & 20.4 & 20.6 \\
\hline $\mathbf{T}_{4}$ & Clean cultivation (weeding at 30 days interval) & 14.8 & 17.7 & 19.9 & 22.5 & 22.6 & 22.3 & 22.7 & 22.6 & 20.5 & 20.4 & 20.6 \\
\hline $\mathbf{T}_{5}$ & Bicolour polythene mulch $(250 \mu \mathrm{m})$ & 15.1 & 18.1 & 21.3 & 23.1 & 23.5 & 23.9 & 24.1 & 23.1 & 23.0 & 22.5 & 21.8 \\
\hline $\mathbf{T}_{6}$ & Paddy straw mulch (10 cm thick) & 14.1 & 17.2 & 19.4 & 22.1 & 22.2 & 22.3 & 22.5 & 21.8 & 20.6 & 20.1 & 20.2 \\
\hline $\mathbf{T}_{7}$ & Oxyflourfen@1.01 ha ${ }^{-1}$ (pre-emergence) & 14.7 & 17.6 & 20.0 & 22.4 & 22.6 & 22.2 & 22.5 & 21.9 & 19.9 & 19.7 & 20.4 \\
\hline $\mathbf{T}_{8}$ & Atrazine@3.0 kg ha ${ }^{-1}$ (pre-emergence) & 14.9 & 17.5 & 19.9 & 22.6 & 22.6 & 22.0 & 22.1 & 21.9 & 20.5 & 19.9 & 20.4 \\
\hline $\mathbf{T}_{9}$ & Pendimethalin@2.01 ha ${ }^{-1}$ (pre-emergence) & 14.6 & 17.8 & 19.8 & 22.3 & 22.5 & 21.9 & 22.0 & 21.6 & 20.2 & 20.1 & 20.3 \\
\hline $\mathbf{T}_{10}$ & $\begin{array}{l}\text { Paddy straw mulch }(10 \mathrm{~cm} \text { thick) followed by } \\
\text { glyphosate @ } 2.01 \mathrm{ha}^{-1} \text { (post-emergence) }\end{array}$ & 14.3 & 17.5 & 19.4 & 22.0 & 22.2 & 22.2 & 21.8 & 21.7 & 20.5 & 20.2 & 20.2 \\
\hline $\mathbf{T}_{11}$ & $\begin{array}{l}\text { Oxyflourfen @ } 1.01 \mathrm{ha}^{-1} \text { (pre-emergence) } \\
\text { followed by glyphosate @ } 2.01 \mathrm{ha}^{-1} \text { (post- } \\
\text { emergence) }\end{array}$ & 14.7 & 17.6 & 19.7 & 22.6 & 22.7 & 22.1 & 22.6 & 22.1 & 20.6 & 20.6 & 20.5 \\
\hline $\mathbf{T}_{12}$ & $\begin{array}{l}\text { Atrazine@ } 3.0 \mathrm{~kg} \mathrm{ha}^{-1} \text { (pre-emergence) } \\
\text { followed by glyphosate @ } 2.01 \mathrm{ha}^{-1} \text { (post- } \\
\text { emergence) }\end{array}$ & 14.6 & 17.5 & 19.8 & 22.7 & 22.7 & 22.4 & 22.8 & 21.8 & 20.5 & 20.1 & 20.5 \\
\hline $\mathrm{T}_{13}$ & $\begin{array}{l}\text { Pendimethalin@ } 2.01 \mathrm{ha}^{-1} \text { (pre-emergence) } \\
\text { followed by glyphosate @ } 2.01 \mathrm{ha}^{-1} \text { (post- } \\
\text { emergence) }\end{array}$ & 14.7 & 17.7 & 19.8 & 22.5 & 22.5 & 22.3 & 22.6 & 22.7 & 20.6 & 20.5 & 20.6 \\
\hline $\mathbf{T}_{14}$ & Cowpea (green manure) & 14.6 & 17.6 & 19.6 & 22.2 & 22.2 & 21.5 & 21.6 & 20.9 & 20.4 & 20.3 & 20.4 \\
\hline $\mathbf{T}_{15}$ & White clover (cover crop) & 14.5 & 17.6 & 19.6 & 22.4 & 22.5 & 22.1 & 22.4 & 22.2 & 19.7 & 19.5 & 20.3 \\
\hline & Mean & 14.6 & 17.6 & 19.8 & 22.5 & 22.6 & 22.3 & 22.4 & 22.0 & 20.5 & 20.2 & \\
\hline & 005 & & & & & & & & & & & \\
\hline & Days & & & & & & & & & & & \\
\hline & Treatments $\times$ Days & & & & & & & & & & & \\
\hline
\end{tabular}


Table.8 Benefit: cost ratio of different orchard floor management practices in apple cv. Royal Delicious (on hectare basis) during 2015 and 2016

\begin{tabular}{|c|c|c|c|}
\hline \multirow{2}{*}{\multicolumn{2}{|c|}{ Treatments }} & \multicolumn{2}{|c|}{ Benefit : cost ratio } \\
\hline & & 2015 & 2016 \\
\hline $\mathbf{T}_{1}$ & Control & - & - \\
\hline $\mathbf{T}_{2}$ & Farmer practices (Hoeing during March and May) & $3.07: 1$ & 3.00:1 \\
\hline $\mathbf{T}_{3}$ & Zero weeds (weeding at frequent intervals) & $3.90: 1$ & 3.93:1 \\
\hline $\mathbf{T}_{4}$ & Clean cultivation (weeding at 30 days interval) & $3.97: 1$ & 3.98:1 \\
\hline $\mathbf{T}_{5}$ & Bicolour polythene mulch $(250 \mu \mathrm{m})$ & 4.89:1 & 4.92:1 \\
\hline $\mathrm{T}_{6}$ & Paddy straw mulch (10 cm thick) & 4.98:1 & $5.01: 1$ \\
\hline $\mathbf{T}_{7}$ & Oxyflourfen@1.01 ha ${ }^{-1}$ (pre-emergence) & $2.72: 1$ & 2.75:1 \\
\hline $\mathrm{T}_{8}$ & Atrazine@ $3.0 \mathrm{~kg} \mathrm{ha}^{-1}$ (pre-emergence) & $2.67: 1$ & 2.68:1 \\
\hline $\mathrm{T}_{9}$ & Pendimethalin@2.01 ha ${ }^{-1}$ (pre-emergence) & 2.70:1 & 2.72:1 \\
\hline $\mathrm{T}_{10}$ & $\begin{array}{l}\text { Paddy straw mulch }(10 \mathrm{~cm} \text { thick) followed by glyphosate } \\
@ 2.01 \mathrm{ha}^{-1} \text { (post-emergence) }\end{array}$ & $5.00: 1$ & $5.05: 1$ \\
\hline $\mathrm{T}_{11}$ & $\begin{array}{l}\text { Oxyflourfen @ } 1.01 \mathrm{ha}^{-1} \text { (pre-emergence) followed by } \\
\text { glyphosate @ } 2.01 \mathrm{ha}^{-1} \text { (post-emergence) }\end{array}$ & $4.45: 1$ & 4.59:1 \\
\hline$T_{12}$ & $\begin{array}{l}\text { Atrazine @3.0 kg ha-1 (pre-emergence) followed by } \\
\text { glyphosate@ } 2.01 \mathrm{ha}^{-1} \text { (post-emergence) }\end{array}$ & $4.41: 1$ & 4.49:1 \\
\hline $\mathbf{T}_{13}$ & $\begin{array}{l}\text { Pendimethalin @ } 2.01 \mathrm{ha}^{-1} \text { (pre-emergence) followed by } \\
\text { glyphosate @ } 2.01 \mathrm{ha}^{-1} \text { (post-emergence) }\end{array}$ & $4.40: 1$ & 4.46:1 \\
\hline $\mathbf{T}_{14}$ & Cowpea (green manure) & $4.95: 1$ & 4.98:1 \\
\hline $\mathbf{T}_{15}$ & White clover (cover crop) & $4.80: 1$ & 4.85:1 \\
\hline
\end{tabular}

\section{Experimental details}

\begin{tabular}{|c|c|}
\hline Treatment Code & Treatment \\
\hline $\mathbf{T}_{1}$ & Control (no weeding) \\
\hline $\mathbf{T}_{2}$ & Farmer practices (Hoeing during March and May) \\
\hline $\mathbf{T}_{3}$ & Zero weeds (weeding at frequent intervals) \\
\hline $\mathbf{T}_{4}$ & Clean cultivation (weeding at 30 days interval) \\
\hline $\mathbf{T}_{5}$ & Bicolour polythene mulch $(250 \mu \mathrm{m})$ \\
\hline $\mathbf{T}_{6}$ & Paddy straw mulch (10 cm thick) \\
\hline $\mathbf{T}_{7}$ & Oxyflourfen@1.01 ha ${ }^{-1}$ (pre-emergence) \\
\hline $\mathbf{T}_{8}$ & Atrazine@3.0 kg ha-1 (pre-emergence) \\
\hline $\mathbf{T}_{9}$ & Pendimethalin@2.01 ha ${ }^{-1}$ (pre-emergence) \\
\hline $\mathbf{T}_{10}$ & $\begin{array}{l}\text { Paddy straw mulch }\left(10 \mathrm{~cm} \text { thick) followed by glyphosate @ } 2.01 \mathrm{ha}^{-1} \text { (post- }\right. \\
\text { emergence) }\end{array}$ \\
\hline $\mathrm{T}_{11}$ & $\begin{array}{l}\text { Oxyflourfen@1.01 ha }{ }^{-1} \text { (pre-emergence) followed by glyphosate @ } 2.01 \text { ha }^{-1} \\
\text { (post-emergence) }\end{array}$ \\
\hline $\mathbf{T}_{12}$ & $\begin{array}{l}\text { Atrazine @ } 3.0 \mathrm{~kg} \mathrm{ha}^{-1} \text { (pre-emergence) followed by glyphosate @ } 2.01 \mathrm{ha}^{-1} \\
\text { (post-emergence) }\end{array}$ \\
\hline $\mathrm{T}_{13}$ & $\begin{array}{l}\text { Pendimethalin@ } 2.01 \mathrm{ha}^{-1} \text { (pre-emergence) followed by glyphosate @ } 2.01 \\
\mathrm{ha}^{-1} \text { (post-emergence) }\end{array}$ \\
\hline $\mathbf{T}_{14}$ & Cowpea (green manure) \\
\hline $\mathbf{T}_{15}$ & White clover (cover crop) \\
\hline
\end{tabular}


The interaction effect of treatments and days after treatments indicate that paddy straw mulch $\left(\mathrm{T}_{6}\right)$ on 15 days recorded maximum soil moisture $(28.27 \%)$ followed by paddy straw mulch followed by glyphosate $\left(\mathrm{T}_{10}\right)$ on 15 days (28.20\%) and on 105 days after treatments $(27.97 \%)$.

The examination of data pertaining to soil moisture content depicted in Table 5 indicated that during 2016, paddy straw mulch followed by glyphosate $\left(\mathrm{T}_{10}\right)$ had maximum soil moisture content (26.01\%) which was statistically at par with paddy straw mulch $(25.95 \%)$ and bicolour polythene mulch (25.09\%). However, maximum soil moisture content $(26.05 \%)$ was recorded on 15 days followed by 105 days (24.37\%).The interaction effect of treatments and days after treatments indicate that the paddy straw mulch on 15 days recorded highest soil moisture content (28.03\%) which was statistically at par with paddy straw mulch followed by glyphosate $\left(\mathrm{T}_{10}\right)$ and bicolour polythene $\left(\mathrm{T}_{5}\right)$ on 15 days, paddy straw mulch $\left(\mathrm{T}_{6}\right)$ from 75 days to 105 days and paddy straw mulch followed by glyphosate $\left(T_{10}\right)$ from 90 days to 105 days.

Mulching with paddy straw mulch followed by glyphosate recorded highest soil moisture content, which was statistically at par with paddy straw mulch and bicolour polythene mulch on 120 days and 45 days after treatments during 2015 and 2016. These results are in conformity with the finding of Rao and Pathak (1998), Pande et al., (2005) and Singh et al., (2010) in aonla, Raina (1991) in apple and Sharma and Kathiravan (2009) in plum. Increased soil moisture content below the mulches in various mulches treatments might be due to reduction in soil surface evaporation, increased infiltration percolation capacity of soil and suppression in extreme fluctuation of soil temperature thus retaining the soil moisture in the soil for longer duration. These result are also in line with Greenham (1953) and Negi (2015) who stated that the general improvement in soil moisture status was likely a consequence of both improved infiltration capacity and reduced evaporation. Bhardwaj and Kumar (2012) reported that black polythene mulch acts as an insulating barrier, which checks evaporation from soil surface and conserves soil moisture. Similar findings were obtained by several researchers (Walsh et al., 1996 and Chandel et al., 2010) who reported comparatively higher soil moisture contents in different mulches over unmulched trees.

Raina (1991) also reported that mulches act as a cover for soil to prevent moisture loss through evaporation and transpiration by weeds aerial parts. Moisture loss was higher under clean basin management, zero weeds and herbicidal treatments, perhaps, because of bare soil surface which caused water loss due to higher evaporation during summer months. In unweeded plants, higher weed population might have extracted more moisture for their growth and development.

\section{Soil temperature}

The data presented in Table 6 indicate that different orchard floor management practices significantly influenced the soil temperature at $0-15 \mathrm{~cm}$ depth during both the years of study. During 2015, maximum soil temperature $\left(20.9{ }^{\circ} \mathrm{C}\right)$ was recorded with bicolour polythene mulch $\left(\mathrm{T}_{5}\right)$ followed by zero weeds and clean cultivation $\left(19.8{ }^{\circ} \mathrm{C}\right)$. Among different days after treatments of observation, significantly maximum soil temperature was recoreded on 105 days closely followed by 90 days. However minimum soil temperature was recorded on 15 days $\left(14.6{ }^{\circ} \mathrm{C}\right)$. The treatments and days interaction effect in respect of soil temperature at $0-15 \mathrm{~cm}$ depth was also significant. Maximum soil temperature 
$\left(23.8^{\circ} \mathrm{C}\right)$ was recorded under bicolour polythene mulch on 90 days which was found to be statistically at par on 105 days and 135 days $\left(23.6{ }^{\circ} \mathrm{C}\right)$ under the same treatment.

Soil temperature at $0-15 \mathrm{~cm}$ depth during 2016 followed the similar pattern as exhibited during 2015 (Table 7). Bicolour polythene mulch $\left(\mathrm{T}_{5}\right)$ recorded significantly higher soil temperature $\left(21.8^{\circ} \mathrm{C}\right)$ followed by clean cultivation $\left(\mathrm{T}_{4}\right)$ and zero weeds $\left(\mathrm{T}_{3}\right)$.

Soil temperature also varied significantly during different days of observation and maximum mean soil temperature $\left(22.6{ }^{\circ} \mathrm{C}\right)$ was recorded on 75 days and minimum mean soil temperature $\left(14.6{ }^{\circ} \mathrm{C}\right)$ was recorded on 15 days. Among treatments and days after treatments interaction, maximum soil temperature $\left(24.1^{\circ} \mathrm{C}\right)$ was recorded under bicolour polythene mulch on 105 days, which was statistically at par with same treatment on 90 days $\left(23.9{ }^{\circ} \mathrm{C}\right)$.

In the present investigation, higher soil temperature was recorded under bicolour polythene mulch on 75 days followed by clean cultivation, while lowest soil temperature was recorded under paddy straw mulch followed by glyphosate on 15 days after treatments. An increase in soil temperature under bicolour mulches may be attributed to the fact that these mulches absorb more radiation from sun and transmit more heat to the upper layer of soil as compared to organic mulches. Various workers (Sharma and Kathiravan, 2009 and Liu et al., 2014) also found an increase in soil temperature with polythene and straw mulches. Walsh et al., (1996) found higher soil temperature under cultivation as compared to straw mulch in apple. Mulches reduces the temperature fluctuation at night, condensation on the underside of the mulch absorbs the long wave radiation emitted by the soil thereby slowing cooling of the soil.
The findings are in line with that of Kumar et al., (1990) and Teodorescu et al., (2013).

Minimum soil temperature under paddy straw mulch may also be due thick grass cover provided by the mulch, thereby preventing atmospheric heat to reach the soil surface. Greenham (1953) reported that organic mulches generally insulate the orchard soil and as a consequence lessen orchard soil temperature variability, reducing daily and annual temperature extremes. Thus, mean soil temperatures beneath mulch in summer are frequently lower under organic mulches (Gormley et al., 1973). Mean monthly temperature at $10 \mathrm{~cm}$ depth below a $10 \mathrm{~cm}$ thick straw cover have frequently been $1^{\circ} \mathrm{C}$ and $2^{\circ} \mathrm{C}$ less than those beneath bare soil in the summer months while during winter similarly measured temperature could be $1^{\circ} \mathrm{C}$ higher under straw mulch relative to bare soil (Weller, 1969). Similar results were also reported by Zhou et al., (2014) who observed that soil water content was increased in the plots treated with organic mulch due to slow soil temperature increase in spring. Organic matter mulch treatments decreased the peak temperature of orchard soil in the summer and increased the minimum soil temperature in the fall.

\section{Economics of production}

\section{Benefit: cost ratio under different orchard floor management practices}

Data pertaining to benefit: cost ratio of each treatment are presented in Table 8. It is evident from the data that different orchard floor management practices in apple orchard observed to be maximum (5.00:1 and 5.05:1) with paddy straw mulch followed by glyphosate $\left(\mathrm{T}_{10}\right)$ followed by paddy straw mulch (4.98:1 and 5.01:1) whereas the minimum benefit: cost ratio (2.67:1 and 2.68:1) was observed with atrazine followed 
by pendimethalin $(2.70: 1$ and 2.72:1). Treatments cowpea $\left(\mathrm{T}_{14}\right)$, bicolour polythene mulch $\left(\mathrm{T}_{5}\right)$ and white clover $\left(\mathrm{T}_{15}\right)$ had satisfactory benefit: cost ratio during 2015 and 2016.

In the present investigation maximum benefit: cost ratio (5.00:1 and 5.05:1) was recorded with paddy straw mulch followed by glyphosate, whereas the minimum benefit: cost ratio was recorded under atrazine followed by pendimethalin. Paddy straw mulch, cowpea and bicolour polythene mulch recorded satisfactory benefit: cost ratio. The increase in benefit: cost ratio may be due to higher yield of good quality fruits under these treatments. The results are in agreement with the findings of Bajwa et al., (2003) in pear and Meena (2013) in peach who reported maximum profitability with grass mulch followed by glyphosate over unweeded control. Similar results were also reported by Chatha and Chanana (2007) who in peach obtained lowest profit over control with oxyflurofen and highest with metolachlor. However, Bajwa and Singh (1992) in pear also recorded maximum profitability in hexuron (herbicide) and minimum in hand weeding.

From the present study entitled "Effect of orchard floor management practices on nutrient status in Apple cv. Royal Delicious" it is concluded that application of paddy straw mulch followed by glyphosate was appreciably effective in improving growth parameters as well as leaf and soil nutrient status. On the other hand, the treatments also significantly improved the cropping which resulted in maximum nutrient status owing to higher efficiency toward elimination of weed during both the years. In general, to meet the multiple objective, paddy straw mulch $(10 \mathrm{~cm}$ thick) followed by glyphosate $\left(2 \mathrm{lha}^{-1}\right)$ provided good weed control in apple orchard and its adoption is beneficial to crop and the soil to represent a good choice in orchard floor management system.

\section{References}

Altland, J. E., Wehtje, G. and Gilliam, C. H. 2003. Weed control in field nurseries. Hort Technology 13: 9-14.

Anonymous, 2016. Annual Progress Report. National Horticulture Board, Government of India.

Anonymous, 2017. Annual Progress Report. Department of Horticulture, J\&K Government, Srinagar pp. 1-2.

Bajwa, G. S. and Singh, D. B. 1992. Note on weed control in Patharnakh nursery. Indian Journal of Horticulture 49(1): 58-59.

Bajwa, G. S., Bal, J. S. and Minhas, P. P. S. 2003. Weed management studies in pear orchards at different locations in Punjab. Haryana Journal of Horticultural Sciences 32(2-4): 180-182.

Bhardwaj, R. L. and Kumar, S. D. 2012. Effect of mulching on crop production under rainfed condition: A Review. International Journal of Research in Chemistry and Environment 2(2): 8-20.

Bhat, D. J. and Khokhar, U. U. 2009. Effect of orchard floor management practices on nutrient status and microbiological activities in apricot orchard. Journal of Research, SKUAST- J 8(1): 50-57.

Booth, B. C., Murphy, S. D. and Swanton, C. J. 2003. Weed Ecology in Natural and Agricultural Systems, CABI Publishing, Oxon p. 303.

Chandel, J. S., Chauhan, N. and Singh, R. 2010. Effect of orchard floor management systems on growth, yield, fruit quality and nutrient contents of kiwifruit (Actinidia deliciosa Chev.). Horticultural Journal 23(1): $1-5$.

Chatha, R. P. S. and Chanana, Y. R. 2007. Studies on weed management in young peach orchards. Indian Journal of Horticulture 64(3): 300-303.

Cooper, A. J. 1973. Root temperature and plant growth. Commonwealth Bur Horticulture Review 4, East Mailing, Maidstone, Kent, UK p. 73. 
Das, K., Sau, S., Sarkar, T. and Dutta, P. 2016. Effect of organic mulches on yield, physico-chemical qualities and leaf mineral composition of litchi cv. Bombai in IndoGangetic plain of West Bengal. Journal of Crop and Weed 12(3): 67-69.

Domange, A. L. 1993. Weed control on the planting row by several mulches in orchards. In: Communications 4th International Conference IFOAM, Nonchemical Weed Control, Dijon, France pp. 367-373.

El-Metwally, I. M. and Hafez, O. M. 2007. Arab University Journal of Agricultural Science, Ain Shams University, Cairo 15(1): 157166.

Forge, T. A., Hogue, E., Neilsen, G. and Neilsen, D. 2003. Effects of organic mulches on soil microfauna in the root zone of apple: implications for nutrient fluxes and functional diversity of the soil food web. Applied Soil Ecology 22: 39-54.

Gormley, R., Robinson, D. and Okennedy, N. 1973. The effect of soil management systems on the chemical composition and quality of apples. Journal of the Science of Food and Agriculture 24: 227-239.

Greenham, D. W. P. 1953. Orchard soil management. 13th International Horticultural Congress, London 1: 181-189.

Hoagland, L., Carpenter, B., Granatstein, D., Mazzol, M., Smith, J., Peryr, F. and Reganold, J. P. 2008. Effect of orchard floor management on nitrogen fertility and soil biological activity in a newly established organic apple orchard. Biology and Fertility of Soils 45: 11-18.

Hogue, E. J. and Neilsen, G. H. 1987. Orchard floor vegetation management. Horticultural Reviews 9: 377-430.

Hogue, E. J., Cline, J. A., Neilsen, G. and Neilsen, D. 2010. Growth and yield response to mulches and cover crops under low potassium conditions in drip-irrigated apple orchards on coarse soils. HortScience 45: 1866-1871.

Ingels, C., Van-Horn, M., Bugg, R. L. and Miller, P. R. 1994. Selecting the right cover crop gives multiple benefits. California Agriculture 48: 43-48.

Jackson, M. L. 1973. Soil Chemical Analysis.
Prentice Hall of India Private Limited, New Delhi pp. 38-82.

Kumar, D. G., Sachin, S. S. and Kumar, R. 1990. Importance of mulch in crop production. Indian Journal of Soil Conservation 18: 2026.

Kumar, J. 1984. Effect of various systems of orchard soil management at different levels of nitrogen in 'Santa Rosa' plum. Ph. D. Thesis, Himachal Pradesh Krishi Vishva Vidyalaya, Palampur (H. P.).

Lakatos, T., Bubán, T. and Helmanczi, B. 2001. Effects on the number of soil microorganisms and tree nutrition of ground cover management systems. ActaHorticulturae 564: 201-207.

Laurent, S. A., Merwin, I. A. and Thies, J. E. 2008. Long-term orchard groundcover management systems affect soil microbial communities and apple replant disease severity. Plant and Soil 304: 209-225.

Liedgens, M., Frossard, E. and Richner, W. 2004 Interactions of maize and Italian ryegrass in a living mulch system: (2) Nitrogen and water dynamics. Plant and Soil 259: 243258.

Lindsay, W. L. and Norvell, W. A. 1978. Development of DTPA soil test for $\mathrm{Zn}, \mathrm{Fe}$, $\mathrm{Mn}$ and $\mathrm{Cu}$. Soil Science Society of American Journal 42: 421-428.

Liu, Y., Wang, J., Liu, D., Li, Z., Zhang, G., Tao, Y., Xie, J., Pan, J. and Chen, F. 2014. Straw mulching reduces the harmful effects of extreme hydrological and temperature conditions in citrus orchards. PLOS One 9(1): e87094.

Majek, B. A., Neary, P. E. and Polk, D. F. 1993. Smooth pigweed interference in newly planted peach trees. Journal of Production Agriculture 6: 244-246.

Marks, M. J. 1993. Preliminary results of an evaluation of alternatives to the use of herbicides in orchards. Proceedings 1993 Brighton Crop Protection Conference Weeds, Brighton, UK pp. 461-466.

Marsh, K. B., Daly, M. J. and McCarthy, T. P. 1996. The effect of understory management on soil fertility, tree nutrition, fruit production and apple fruit quality. Biological Agriculture and Horticulture 13: 161-173. 
Meena, M. K. 2013. Effect of different weed management practices on growth, yield and fruit quality of peach (Prunus persica Batsch) cv. July Elberta. Thesis submitted to Dr. Yashwant Singh Parmar University of Horticulture and Forestry, Solan (H. P.).

Meena, M. K., Sharma, D. D. and Meena, O. P. 2015. Effect of different weed management practices on weed population, yield potential and nutrient status of peach cv. July Elberta. Research on Crops 16 (3): 519-525.

Merwin, I. A. 2004. Groundcover management effects on orchard production, nutrition, soil and water quality. New York Fruit Quarterly 12(2): 25-29.

Merwin, I. A. and Stiles, W. C. 1994. Orchard groundcover management impacts on apple tree growth and yield and nutrient availability and uptake. Journal of American Society for Horticultural Science 119: 209-215.

Merwin, I. A., Rosenberger, D. A., Engle, C. A., Rist, D. L. and Fargione, M. 1995. Comparing mulches, herbicides and cultivation as orchard groundcover management system. HortTechnology 5(2): 151-158.

Negi, P. K. 2015. Effect of orchard floor management practices on growth, cropping and quality of nectarine [Prunuspersica (L.) Batsch var. nucipersica] cv. Snow Queen. M. Sc. Thesis submitted to Dr. Yashwant Singh Parmar University of Horticulture and Forestry, Solan (H. P.).

Neilsen, G. H. and Neilsen, D. 2003. Nutritional requirements of apples. In: Apples: Botany, production and uses (Eds. D. C. Ferree and I. J. Warrington) CABI Publ., Wallingford, UK pp. 266-300.

Neilson, G. H., Hoyt, P. B. and Lan, O. L. 1982. Effect of surface soil $\mathrm{pH}$ on soil cation content, leaf nutrient levels and quality of apples in British Columbia. Canadian Journal of Plant Science 62: 695-702.

Pande, K. K., Dimri, D. C. and Prashant, K. 2005. Effect of various mulches on growth, yield and quality attributes of apple. Indian Journal of Horticulture 62(2): 145-147.

Raese, J. T. 1990. Apple and pear yield influenced by weeds and nitrogen. Good Fruit Grower
41(2): 4-5.

Raina, S. S. 1991. Effect of herbicides, mulching and clean cultivation on the growth, yield, quality and leaf nutrient content of Royal Delicious apple trees. M. Sc. Thesis, Dr Y. S. Parmar University of Horticulture and Forestry, Nauni, Solan (H.P.).

Rao, V. K. and Pathak, R. K. 1998. Effect of mulches on aonla (Emblica officinalis Gaertn) orchard in sodic soil. Indian Journal of Horticulture 55: 27-37.

Sanchez, J. E., Edson, C. E., Bird, G. W., Whalon, M. E., Willson, T. C., Harwoord, R. R., Kizilkaya, K., Nugent, J. E., Klein, W., Middleton, A., Loudon, T. L., Mutch, D. R. and Scrimger, J. 2003. Orchard floor and nitrogen management influences soil and water quality and Tart cherry yields. Journal of American Society for Horticulture Science 128(2): 277-284.

Sas-Paszt, L., Pruski, K., Zurawicz, E., Sumorok, B., Derkowska, E. and Gluszek, S. 2014. The effect of organic mulches and mycorrhizal substrate on growth, yield and quality of Gold Milenium apples on M. 9 rootstock. Canadian Journal of Plant Science 94: 281-291.

Schutt, M., Borken, W., Spott, O., Stange, C. F. and Matzner, E. 2014. Temperature sensitivity of $\mathrm{C}$ and $\mathrm{N}$ mineralization in temperate forest soils at low temperatures. Soil Biology and Biochemistry 69: 320-327.

Sharma, J. C. and Kathiravan, G. 2009. Effect of mulches on soil hydrothermal regimes and growth of plum in mid hill region of Himachal Pradesh. Indian Journal of Horticulture 66(4): 465-471.

Shear, C. B. and Faust, M. 1980. Nutrient ranges in deciduous tree fruits and nuts. Horticultural Reviews 2: 142-163.

Shylla, B. and Chauhan, J. S. 2004. Influence of orchard floor management practices on cropping and quality of Santa Rosa plum grown under mid-hill conditions. Acta Horticulturae 662: 213-216.

Shylla, B., Chauhan, J. S., Awasthi, R. P. and Bhandari, A. R. 1999. Effect of orchard floor management practices on leaf nutrient status of plum. Indian Journal of Horticulture 56(1): 34-37.

Singh, A. K., Singh, S., Appa Rao, V. V., Bagle, 
B. G. and More, T. A. 2010. Efficacy of organic mulches on soil properties, earthworm population, growth and yield of aonla cv. NA7 in semi- arid ecosystem. Indian Journal of Horticulture 67: 124-128.

Singh, D. B. and Pal, A. A. 2013. Apple. In: Fruit production in India (Ed.W. S. Dhillon) Narendra Publishing House, Delhi, India pp. 31-57.

Skroch, W. A. and Schribbs, J. M. 1986. Orchard floor management: an overview. HortScience 21: 390-394.

Szewczuk, A. and Gudarowska, E. 2004. Effect of different types of mulching on yield, size, colour and storability of 'Jonagored' apples. Journal of Fruit and Ornamental Plant Research 14: 135-141.

Teodorescu, G., Cosac, A. C., Frasin, L. B. and Morarita, S. 2013. Sustainable technology of soil in orchards and environmental protection. ActaHorticulturae 981: 367372.

Varadi, G., Polos, E. and Mikulas, J. 1989. Digitaria- a possible tool for weed control in ineyards. In: Proceedings $4^{\text {th }}$ EWRS Mediterranean symposium on weed problems in Mediterranean climates, 2. Problems of weed control in fruit, horticultural crops and rice, Valencia, Spain pp. 203-210.

Walsh, B. D., Salmins, S., Buszard, D. J. and MacKezie, A. F. 1996. Impact of soil management system on organic dwarf apple orchards and soil aggregate stability, bulk density, temperature and water content. Canadian Journal of Soil Science 76: $203-$
209.

Wani, W. M., Dar, K. A., Bhat, R. and Wani, N. 2013. Influence of orchard management strategies on growth, yield, quality and leaf mineral concentrations in cherry cv. 'Bigarreau Noir Gross (MISRI). Applied Biological Research 15(1): 21-26.

Weller, F. 1969. Influencing the soil temperature in orchard by different methods of soil care. Erwerbs-Obstbau 9: 169-173.

Wheeler, G. F., William, D. G., Michael, G. P., Kenneth, M. T., Alfred, W. D., Laura, S. T. and James, S. B. 1999. Organic mulches affect soil and leaf nutrient levels of young pecan trees. Journal of Arboriculture 25(2): 81-85.

Yao, S., Merwin, I. A., Bird, G. W., Abawi, G. S. and Thies, J. E. 2005. Orchard floor management practices that maintain vegetative or biomass groundcover stimulate soil microbial activity and alter soil microbial community composition. Plant and Soil 71: 377-389.

Yin, X., Seavert, C. F., Turner, J., Nunez-Elisea, R. and Cahn, H. 2007. Effects of polypropylene groundcover on soil nutrient availability, sweet cherry nutrition and cash costs and returns. HortScience 42(1): 147151.

Zhou, J. T., Lu, D. G. and Qin, S. J. 2014. Effects of different organic matter mulching on water content, temperature and available nutrients of apple orchard soil in a cold region. Yingong Sheng Tai XueBao 25(9): 2551-2556.

\section{How to cite this article:}

Shabber Hussain, M.K. Sharma, D. Bashir, P. Tundup, S.A. Bangroo and Kumar, A. 2018. Effect of Orchard Floor Management Practices on Nutrient Status in Apple cv. Royal Delicious. Int.J.Curr.Microbiol.App.Sci. 7(02): 2771-2792.

doi: https://doi.org/10.20546/ijcmas.2018.702.338 